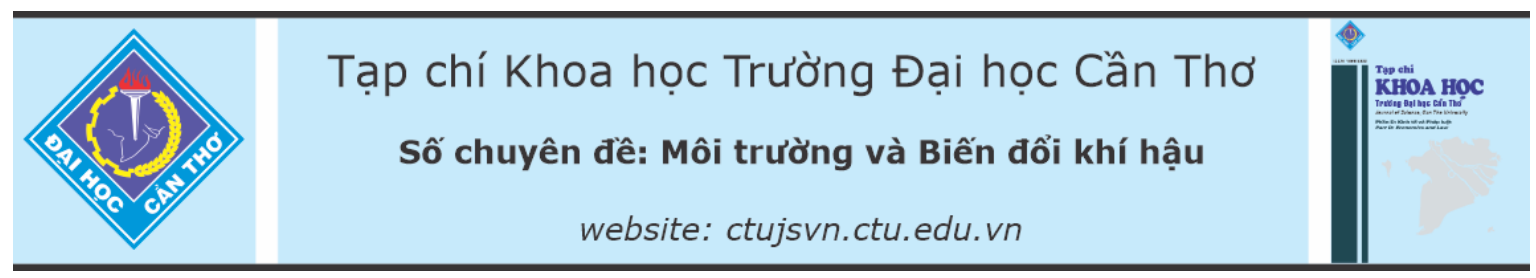

DOI:10.22144/ctu.jsi.2021.032

\title{
ẢNH HƯỞNG CỦA MARSHAL 200SC ĐẾN CHOLINESTERASE VÀ TĂNG TRƯỞNG CÁ MÈ VINH (Barbonymus gonionotus)
}

\author{
Nguyễn Văn Công ${ }^{1 *}$, Huỳnh Thị Diễm ${ }^{1}$, Trần Thị Thanh Xuân ${ }^{2}$, Trần Sỹ Nam ${ }^{1}$ và Bùi Thị Bích Hằng ${ }^{3}$ \\ ${ }^{1}$ Khoa Môi trường và Tài nguyên Thiên nhiên, Truờng Đại học Cần Tho \\ ${ }^{2}$ Sinh viên ngành Khoa học môi trường, Khoa Môi trường và Tài nguyên Thiên nhiên, Trường Đại học Cần Tho \\ ${ }^{3}$ Khoa Thuỷ sản, Truòng Đại học Cần Tho \\ *Người chịu trách nhiệm về bài viết: Nguyễn Văn Công (email: nvcong@ctu.edu.vn)
}

\section{Thông tin chung:}

Ngày nhận bài: $12 / 04 / 2021$

Ngày nhận bài sủa: 25/10/2021

Ngày duyệt đăng: 15/11/2021

Title:

Effects of Marshal 200SC on cholinesterase and growth of silver barb (Barbonymus gonionotus)

\section{Tù khóa:}

Barbonymus gonionotus, Carbosulfan, cholinesterase, độc học thủy vưcc, tăng trọng

\section{Keywords:}

Aquatic toxicology,

Barbonymus gonionotus, Carbosulfan, cholinesterase, growth

\begin{abstract}
Marshal 200SC containing carbosulfan 200g/L has been used in rice crop in the Mekong delta. Toxic mechanism of carbosulfan for organisms is cholinesterase (ChE) inhibition. Silver barb (Barbonymus gonionotus) distributes in variety waterbodies and is cultured in integrated rice - fish system in the Mekon $g$ delta. Therefore, this species would be a high risk of exposure to the use of this pesticide. This study aimed to determine the effects of sub-lethal concentrations of this pesticide on ChE activities and growth performance of silver barb. Three sub-lethal concentrations (1, 10 and 20\% LC50-96h) of this pesticide were conducted in laboratory condition for assessing effects of Marshall 200SC on ChE in 96h and on the growth of fingerlings in 60 days. Results showed that LC50-96h of Marshal 200SC for this species is 1.375 ppm (equivalent $0.275 \mathrm{mg} / \mathrm{L}$ Carbosulfan). Brain ChE of the fish is more sensitive with Marshal 200SC than growth performances. ChE activity was inhibited $18.4 \%$ at concentration of 1\%LC50-96h. At the concentration of 20\%LC50-96h, FCR and FI increased up to $129.6 \%$ and $116.7 \%$ of control respectively, but SGR decreased to 74,5\% of control. Investigate effects of Marshal 200SC for this fish species in field condition needs to be carried out.
\end{abstract}

\section{TÓM TẮT}

Marshal 200SC chứa carbosulfan 200g/L đượ sủ dụng trong canh tác lúa ở Đồng bà̀ng sông Cửu Long. Carbosulfan có cơ chế gây hại cho sinh vật qua ức chế cholinesterase (ChE). Cá mè vinh (Barbonymus gonionotus) sống ở nhiều thủy vực và được nuôi xen canh trong mô hình lúa - cá nên có nhiều nguy co tiếp xúc và bị ảnh hưởng do sử dụng thuốc này. Nghiên cứu này nhằm xác định ảnh hưởng ở nồng độ dưới ngưỡng gây chết của Marshal 200SC đến ChE và tăng truơơng của loài cá này. Ba nồng độ Marshall 200SC $(1,10$ và 20\%LC50-96 giờ) được triển khai trong điều kiện phòng thí nghiệm để đánh giá ảnh hưởng của thuốc đến ChE trong 96 giờ và đến tăng trưởng cá trong 60 ngày. Kết quả cho thấy Marshal 200SC chứa carbosulfan $200 \mathrm{~g} / \mathrm{L}$ có đồ độc cấp tính cao đối với cá mè vinh cỡ giống, giá trị LC50-96 giờ của thuốc đối với loài cá này là 1,375 ppm (\# 0,275 mg/L carbosulfan). Thông số ChE trong não cá mè vinh nhay cảm với Marshal 200SC hơn các thông số tăng trương. Ở nồng độ 1\%LC50-96 giò̀, thuốc đã làm ức chế 18,4\% hoạt tính ChE; trong khi ở nồng độ 20\%LC50-96 giờ, thuốc làm FCR và FI tăng lần luợt bằng $129,6 \%$ và $116,7 \%$ đối chứng nhưng SGR giảm còn $74,5 \%$ đối chứng. Nghiên cứu ảnh hưởng của Marshal 200SC đến cá ở điều kiện ruộng lúa là cần được triển khai. 


\section{GIỚI THIỆU}

Đồng bằng sông Cửu Long (ĐBSCL) là vùng canh tác lúa trọng điểm của Việt Nam. Với tổng diện tích của vùng chiếm khoảng $12 \%$ tổng diện tích cả nước nhưng sản lượng lúa đóng góp luôn ở mức trên $50 \%$ sản lượng lúa Việt Nam. Để đảm bảo được sản lượng lúa, việc gia tăng diện tích trồng và mức độ thâm canh đã không ngừng được thực hiện. Nghiên cứu của Berg and Tam (2012) cho thấy thuốc BVTV được sử dụng 5-7 lần/vụ. Con số này không giảm dù đã có nhiều tuyên truyền 3 phải, 5 giảm trong canh tác lúa (Nguyễn Văn Toàn và Nguyễn Văn Công, 2018).

Bên cạnh những lợi ích mang lại, thuốc bảo vệ thực vật (BVTV) cũng là một trong tác nhân gây mất ổn định môi trường, gây ô nhiễm nguồn nước và đất, để lại dư lượng trên nông sản, gây độc cho người và nhiều loài động vật máu nóng (Nguyễn Trần Oánh và ctv., 2007). Sử sụng thuốc BVTV trong canh tác lúa ở ĐBSCL làm ảnh hưởng đến cá lóc (Channa striata) (Cong et al., 2008), cá rô đồng (Anabas testidineus) (Tam et al, 2018).

Carbosulfan là một trong những loại thuốc BVTV được sử dụng trong canh tác lúa. Danh mục thuốc bảo vệ thực vật cho phép sử dụng ở Việt Nam năm 2020 có đến 8 tên thuốc thương mại chứa hoạt chất carbosulfan (Bộ Nông nghiệp và phát triển nông thôn, 2020). Các thuốc chứa hoạt chất này như Marshal 200SC, Afudan 3GR, 20SC, Carbosan 25EC... Hoạt chất carbosulfan thuộc nhóm carbamate (Tomlin, 1994), có cơ chế gây hại cho động vật thông qua gây ức chế hoạt tính cholinesterase (Stenersen, 2004). Khi enzyme cholinesterase bị ức chế sẽ kéo theo nhiều ảnh hưởng nghiêm trọng khác cho sinh vật (Fulton \& Key, 2001) như ảnh hưởng đến tăng trưởng cá lóc (Cong et al., 2009), cá mè vinh (Barbonymus gonionotus) (Cong et al., 2021) và đo enzyme cholinesterase có thể cảnh báo sớm ảnh hưởng tiêu cực của thuốc cho sinh vật (Cong et al., 2006). Marshal 200SC chứa 200g/L hoạt chất carbosulfan được sử dụng để diệt trừ sâu đục thân, rầy nâu/ lúa, rệp sáp, ve sầu (BNNPTNT, 2020).

Cá mè vinh là loài cá nước ngọt, phân bố trong nhiều loại hình thủy vực (Trương Thủ Khoa \& Nguyễn Thị Thu Hương, 1993) và được thả nuôi phổ biến trong mô hình cá - lúa ở các tỉnh ĐBSCL (Võ Văn Hà và ctv., 2004). Ruộng lúa cũng là nơi được sử dụng quá mức thuốc trừ sâu (Nguyễn Văn Toàn \& Nguyễn Văn Công, 2018). Do đó, loài cá này có nhiều nguy cơ bị ảnh hưởng. Nghiên cứu này được thực hiện nhằm xác định được $\mathrm{LC}_{50}$ của thuốc BVTV Marshal 200SC đối với cá mè vinh cỡ giống và ảnh hưởng ở nồng độ dưới ngưỡng gây chểt của thuốc đến hoạt tính cholinesterase ở loài cá này; từ đó giúp cảnh báo rủi ro của việc sử dụng carbosulfan đến loài cá này.

\section{PHƯƠNG PHÁP NGHIÊN CÚU}

\subsection{Thời gian và địa điểm nghiên cứu}

Nghiên cứu được thực hiện tại phòng thí nghiệm Khoa Môi trường và Tài nguyên Thiên nhiên thuộc khu II, Trường Đại học Cần Thơ từ tháng 7 đến tháng 12/2018.

\subsection{Vật liệu thí nghiệm}

\subsubsection{Thuốc thí nghiệm}

Thuốc trừ sâu Marshal 200SC chứa 200g/L hoạt chất Carbosulfan do công ty FMC Corporation (USA) sản xuất được sử dụng cho thí nghiệm.

\subsubsection{Sinh vật thí nghiệm}

Cá mè vinh (2,5 - 4 gram/con) được mua từ trại cá giống tại huyện Châu Thành - tỉnh Hậu Giang và thuần dưỡng 14 ngày cho quen môi trường nuôi dưỡng nước sử dụng cho thí nghiệm. Cá khỏe mạnh, không dị tật, không có dấu hiệu bệnh và đồng cỡ được lựa chọn cho nghiên cứu.

\subsection{Phương pháp bố trí thí nghiệm}

2.3.1. Phưong pháp xác định nồng độ gây chết $50 \%$ cá mè vinh $\left(L C_{50}-96\right.$ giò)

Nồng độ gây chết $50 \%$ cá mè vinh theo thời gian được xác định qua bố trí thí nghiệm theo phương pháp nước tĩnh, không thay nước (APHA, 1998). Thí nghiệm được tiến hành qua 2 bước:

\section{Thi nghiệm xác định khoảng gây độc}

Thí nghiệm được bố trí 9 mức nồng độ $0,2,0,4$, $0,8,1,55,3,15,6,25,12,5,25,50 \mathrm{ppm}$ và 1 nghiệm thức đối chứng (20L nước máy/lần lặp lại). Thí nghiệm này được triển khai theo hệ thống nước tĩnh, không thay nước trong bể composite 60L. Mỗi bể bố trí 10 cá. Cá chết ở từng nghiệm thức được ghi nhận ở $3,6,9,12,24,36,60,72,84$ và 96 giờ để ước tính khoảng gây độc, làm căn cứ xác định khoảng nồng độ bố trí thí nghiệm xác định LC50-96 giờ.

\section{Thi nghiệm xác định $\mathrm{LC}_{50}-96$ giò̀}

Khoảng gây độc được chọn từ 1,0 -3,0ppm. Thí nghiệm được bố trí hoàn toàn ngẫu nhiên gồm 6 nồng độ $(1,00,1,25,1,55,1,90,2,40,3,00$ ppm) nằm trong khoảng gây độc và đối chứng (nước máy đã sụt khí 48 giờ để loại bỏ chlor dư). Mỗi nồng độ 
được lặp lại 3 lần dùng bể composite sợi thủy tinh 60 lít. Mỗi lần lặp lại được thả 10 cá. Trong thời gian thí nghiệm, không thay nước, không cho cá ăn và ghi nhận số cá chết ở các thời điểm: $1,3,6,9,12$, $24,36,48,60,72,84$ và 96 giờ sau khi bố trí. Khi phát hiện cá chết, số liệu được ghi nhận trước rồi dùng vợt vớt ra để tránh ảnh hưởng đến chất lượng nước thí nghiệm do xác cá chết thối rửa.

Nhiệt độ, $\mathrm{pH}$ và oxy hòa tan được đo hàng ngày (7:00 - 8:00 và 14:00 - 15:00). Nhiệt độ được đo bằng nhiệt kế rượu. $\mathrm{pH}$ được đo bằng máy Hanna (HI 8314, Rumani) và $\mathrm{DO}$ được đo bằng máy Hanna (HI 9146, Rumani).

\subsubsection{Xác định độ nhạy cảm của enzyme Cholinesterase (ChE) cá mè vinh với Marshal 200SC}

Nồng độ an toàn cho sinh vật thường bằng 1 10\% LC50 - 96 giờ (Lê Huy Bá, 2000). Do đó, thí nghiệm được thực hiện gồm nghiệm thức đối chứng và 3 nghiệm thức chứa Marshal $200 \mathrm{SC}(1,10$ và $20 \%$ LC50-96 giờ tương đương $0,0138,0,1376$ và 0,275 ppm Marshal 200SC), được bố trí hoàn toàn ngẫu nhiên với 3 lần lặp lại trong 96 giờ. Mỗi nghiệm thức được chuẩn bị $25 \mathrm{~L}$ dung dịch cho vào bể composite sợi thủy tinh $60 \mathrm{~L}$, mỗi bể thả 25 cá.

Trong thời gian bố trí là 96 giờ cá không được cho ăn hay thay nước, nước không được khuấy trộn. Hàng ngày, nhiệt độ, oxy hòa tan và $\mathrm{pH}$ được đo vào lúc 6:00-7:00 và 14:00 - 15:00.

Cá được thu ở các thời điểm: $0,3,6,9,12,24$, 48, 72 và 96 giờ sau khi bố trí cá vào thuốc để đo enzyme $\mathrm{ChE}$ trong não. Mỗi lần thu mẫu, thu 6 cá/nồng độ (2 cá/bể) rồi giết nhanh bằng cách cho vào nước đá để hạn chế làm sốc cá và ảnh hưởng đến $\mathrm{ChE}$. Quá trình mổ lấy não và xử lý mẫu được thực hiện theo quy trình đã được công bố (Cong et al., 2006). Phân tích $\mathrm{ChE}$ được thực hiện theo phương pháp của Ellman et al., (1961).

\subsubsection{Xác định ảnh huởng của Marshal 200SC ở nồng độ duới nguõ̃ng gây chết đến tăng trương cá mè vinh}

Ba mức nồng độ Marshal 200SC $(1,10$ và $20 \%$ LC50-96 giờ tương đương $0,0138,0,1376$ và 0,275 ppm Marshal 200SC) và đối chứng (nước máy) được bố trí hoàn toàn ngẫu nhiên trong bể composite 600L chứa 300 lít dung dịch thuốc (nước máy qua sụt khí 48 giờ cho đối chứng). Mỗi nồng độ được bố trí lặp lại 3 lần. Cá được cân khối lượng ban đầu cho từng con trước khi bố trí, mỗi lần lặp lại được bố trí 30 cá. Trong 2 ngày kể từ khi cho thuốc vào, cá không ăn vì bị stress. Do đó, cá không được cho ăn để hạn chế thức ăn làm bẩn nước. Sau đó được cho ăn hằng ngày vào lúc 9-10 giờ và $16-17$ giờ bằng thức ăn viên (Cargil, 30\% đạm) với lượng thức ăn bằng $5 \%$ khối lượng cá trong bể. Sau khi cho ăn khoảng 45 phút, thức ăn thừa được vớt ra rồi đếm số viên thức ăn còn dư để tính lượng thức ăn mà cá đã sử dụng. Các bể thí nghiệm được sụt khí liên tục trong thời gian thí nghiệm. Từng cá được cân riêng khối lượng bằng cân điện tử và đo chiều dài tổng bằng thước với chu kỳ 15 ngày/lần. Trước khi cân ngưng cho cá ăn một ngày. Các cá chết cũng được ghi nhận và cân khối lượng để tính tỷ lệ chết. Do thời gian cách ly của thuốc là $14-15$ ngày nên các bể thí nghiệm định kỳ 15 ngày thay mới nồng độ Marshal 200SC như bố trí ban đầu. Thí nghiệm được bố trí trong 60 ngày. Các thông số môi trường như $\mathrm{pH}, \mathrm{DO}$, nhiệt độ, $\mathrm{NO}_{2}{ }^{-}$và $\mathrm{NH}_{3} / \mathrm{NH}_{4}{ }^{+}$được đo với chu kỳ 3 ngày/lần, đo vào lúc 7-8 giờ và $14-15$ giờ.

\subsection{Phương pháp tính toán và xử lý số liệu}

\subsubsection{Cách tính toán số liệu}

$\mathrm{LC}_{50}$ được ước tính bằng phương pháp probit (Finney, 1971). Trong đó, nồng độ được chuyển sang logaric thập phân.

Hoạt tính của ChE được tính theo công thức:

$$
H T=\frac{A x C_{v} x H_{v}}{E x L x S_{v} x P_{s}}
$$

Trong đó, HT: hoạt tính $\mu \mathrm{M} / \mathrm{g} / \mathrm{phút}$, A: Abs mẫu - Abs blank (Abs/phút), $\mathrm{C} v$ : thể tích cuvet hay tổng thể tích dung dịch đo $(\mathrm{mL})=3 \mathrm{~mL}, \mathrm{H} v$ : thể tích buffer sử dụng để nghiền mẫu $(\mathrm{mL}), \mathrm{E}$ : hệ số=13,6, $\mathrm{L}$ : chiều dài cuvet $(\mathrm{cm})=1 \mathrm{~cm}, \mathrm{~S} v$ : thể tích mẫu sau khi ly tâm lấy đo $(\mathrm{mL})=0,2 \mathrm{~mL}$, Ps: trọng lượng mẫu lấy nghiền $(\mathrm{g})$.

Tỷ lệ enzyme ChE bị ức chế được tính theo công thức:

$$
I=100-\frac{A}{A_{d c}} 100
$$

Trong đó, I: tỉ lệ ChE bị ức chế (\%), A: là hoạt tính ChE đo được từng mẫu $(\mu \mathrm{M} / \mathrm{g} /$ phút), $\mathrm{A} d c$ : là trung bình hoạt tính $\mathrm{ChE}$ của nghiệm thức đối chứng ở từng thời điểm $(\mu \mathrm{M} / \mathrm{g} / \mathrm{phút})$.

Tỷ lệ chết được tính theo công thức:

Tỷ lệ chết $(\%)=\frac{N}{N_{0}} \times 100$

Trong đó: $\mathrm{N}$ : là số cá chết trong từng bể (con/bể)

$\mathrm{N}_{0}$ : là số cá bố trí ban đầu (con/bể) 
Tốc độ tăng trưởng tương đối (SGR) được tính theo công thức:

$$
\mathrm{SGR}=\frac{\operatorname{Ln}\left(\mathrm{W}_{\mathrm{t})}-\mathrm{Ln}\left(\mathrm{W}_{0}\right)\right.}{\mathrm{T}} \times 100
$$

Trong đó: SGR: Tốc độ tăng trưởng tương đối (\%/ngày)

$\mathrm{W}_{\mathrm{o}}$ : Trung bình khối lượng ban đầu $(\mathrm{g})$

$\mathrm{W}_{\mathrm{t}}$ : Trung bình khối lượng cuối $(\mathrm{g})$

$\mathrm{T}$ : Thời gian nuôi (ngày)

Lượng thức ăn tiêu thụ được tính theo công thức sau:

$$
\mathrm{FI}=\frac{\sum F_{c}-\sum F_{r}}{\sum W x T}
$$

Trong đó: FI: Lượng thức ăn tiêu thụ ((mg/g.ngày)

(mg)

$\Sigma \mathrm{F}_{\mathrm{c}}$ : Tổng lượng thức ăn cho ăn

$\Sigma \mathrm{F}_{\mathrm{r}}$ : Tổng lượng thức ăn thừa $(\mathrm{mg})$ (g)

$\Sigma \mathrm{W}$ : Tổng khối lượng cá tính đến thời điểm $\mathrm{T}$

T: Thời gian thí nghiệm (ngày)

Hệ số chuyển hóa thức ăn (FCR) được tính theo công thức sau:

$$
\mathrm{FCR}=\frac{\sum \mathrm{F}_{\mathrm{c}}-\sum \mathrm{F}_{\mathrm{r}}}{\left(\sum \mathrm{W}_{\mathrm{f}}-\sum \mathrm{W}_{\mathrm{i}}+\sum \mathrm{W}_{\mathrm{m}}\right)}
$$

Trong đó: FCR: hệ số chuyển hóa thức ăn

$$
\sum \mathrm{F}_{\mathrm{c}} \text { : Tổng lượng thức ăn cho cá ăn (g) }
$$

(g)

$\sum \mathrm{F}_{\mathrm{r}}$ : Tổng lượng thức ăn thừa sau khi cho cá ăn (g)

$\sum \mathrm{W}_{\mathrm{f}}$ : Tổng khối lượng cá ở thời điểm khảo sát

$\sum \mathrm{W}_{\mathrm{i}}$ : Tổng khối lượng cá lúc đầu $(\mathrm{g})$

$\sum \mathrm{W}_{\mathrm{m}}$ : Tổng khối lượng cá chết $(\mathrm{g})$

2.4.2. Xử lý số liệu

Số liệu ChE, tỷ lệ chêt, FI, FCR, SGR, trọng lượng ướt được kiểm tra phân phối chuẩn và tính đồng nhất về phương sai trước khi áp dụng thống kê. Số liệu phân phối chuẩn và đồng nhất phương sai được phân tích one-way ANOVA và áp dụng kiểm định Duncan để xem xét sai khác giữa các trung bình. Sai khác có ý nghĩa thống kê được tính khi $\mathrm{p}<0,05$.

\section{KÊTT QUẢ VÀ THẢO LUẬN}

\subsection{Giá trị $L C_{50}$ của Marshal $200 S C$ đối với cá mè vinh}

\subsubsection{Các yếu tố môi truờng}

Kết quả (Bảng 1) cho thấy nhiệt độ trung bình dao động từ $28,3-31^{\circ} \mathrm{C}$; nhiệt độ buổi chiều cao hơn buổi sáng $1-2,7^{\circ} \mathrm{C}$ nhưng nhiệt độ trung bình không khác biệt lớn ở các bể thí nghiệm trong cùng buổi. Giá trị pH trong quá trình thí nghiệm dao động trong khoảng 7,2 - 7,4. Ở các bể thí nghiệm, DO trung bình dao động quanh $3,2 \mathrm{mg} / \mathrm{L}$. Loài cá này chỉ hô hấp dựa vào $\mathrm{DO}$ trong nước nên hàm lượng DO này khá thấp cho cá mè vinh. DO thấp có thể làm cá tăng cường độ hô hấp, tăng hấp thu thuốc vào cơ thể. Tuy nhiên, lượng oxy gần như đồng nhất giữa các nghiệm thức ở từng thời điểm.

Nhìn chung, các thông số môi trường theo dõi trong quá trình thí nghiệm khá ổn định và gần như đồng nhất giữa các bể.

Bảng 1: Nhiệt độ, $\mathrm{DO}$ và $\mathrm{pH}$ ở các nghiệm thức trong thời gian thí nghiệm

\begin{tabular}{lrrrrrr}
\hline Nồng độ Marshal & \multicolumn{2}{c}{ Nhiệt độ $\left({ }^{\circ} \mathbf{C}\right)$} & \multicolumn{2}{c}{ DO $(\mathbf{m g} / \mathbf{L})$} & \multicolumn{2}{c}{ pH } \\
\cline { 2 - 7 } 200SC $(\mathbf{p p m})$ & Sáng & Chiều & Sáng & Chiều & Sáng & Chiều \\
\hline ĐC & $28,67 \pm 0,13$ & $31,00 \pm 0,22$ & $3,2 \pm 0,2$ & $3,2 \pm 0,4$ & $7,2 \pm 0,1$ & $7,3 \pm 0,4$ \\
0,20 & $28,50 \pm 0,12$ & $30,71 \pm 0,21$ & $3,2 \pm 0,4$ & $3,2 \pm 0,7$ & $7,3 \pm 0,2$ & $7,2 \pm 0,4$ \\
0,25 & $28,46 \pm 0,18$ & $30,46 \pm 0,21$ & $3,2 \pm 0,1$ & $3,2 \pm 0,6$ & $7,2 \pm 0,1$ & $7,3 \pm 0,4$ \\
0,31 & $28,42 \pm 0,14$ & $30,17 \pm 0,22$ & $3,2 \pm 0,3$ & $3,2 \pm 0,3$ & $7,2 \pm 0,3$ & $7,4 \pm 0,4$ \\
0,38 & $28,42 \pm 0,14$ & $29,92 \pm 0,19$ & $3,2 \pm 0,5$ & $3,2 \pm 0,8$ & $7,3 \pm 0,1$ & $7,3 \pm 0,4$ \\
0,48 & $28,54 \pm 0,18$ & $29,67 \pm 0,19$ & $3,2 \pm 0,7$ & $3,2 \pm 0,9$ & $7,2 \pm 0,3$ & $7,2 \pm 0,4$ \\
0,60 & $28,33 \pm 0,11$ & $29,50 \pm 0,15$ & $3,2 \pm 0,6$ & $3,2 \pm 0,5$ & $7,3 \pm 0,4$ & $7,4 \pm 0,4$ \\
\hline
\end{tabular}

(Số liệu trình bày: Trung bình \pm độ lêch chuẩn) 


\subsubsection{Tỷ lệ chết theo thời gian}

Kết quả (Hình 1) cho thấy ở nghiệm thức đối chứng không có cá chết. Ở nghiệm thức thuốc, cá bắt đầu chết từ 1 giờ phơi nhiễm trở về sau và chết tập trung chủ yếu từ 3 đến 48 giờ; sau đó số cá chết ở các nghiệm thức không thay đổi. Tỷ lệ chết từ 48 giờ ở các nồng độ $1 \mathrm{ppm}, 1,25 \mathrm{ppm}, 1,55 \mathrm{ppm}, 1,90$ $\mathrm{ppm}, 2,40 \mathrm{ppm}$ và $3 \mathrm{ppm}$ lần lượt là $20 \%, 46,7 \%$, $63,3 \%, 83,3 \%$ và $96,7 \%$. Qua đó cho thấy tỷ lệ cá chết tăng dần theo sự gia tăng nồng độ thuốc. Carbosulfan gây chết nhanh nhưng không kéo dài.

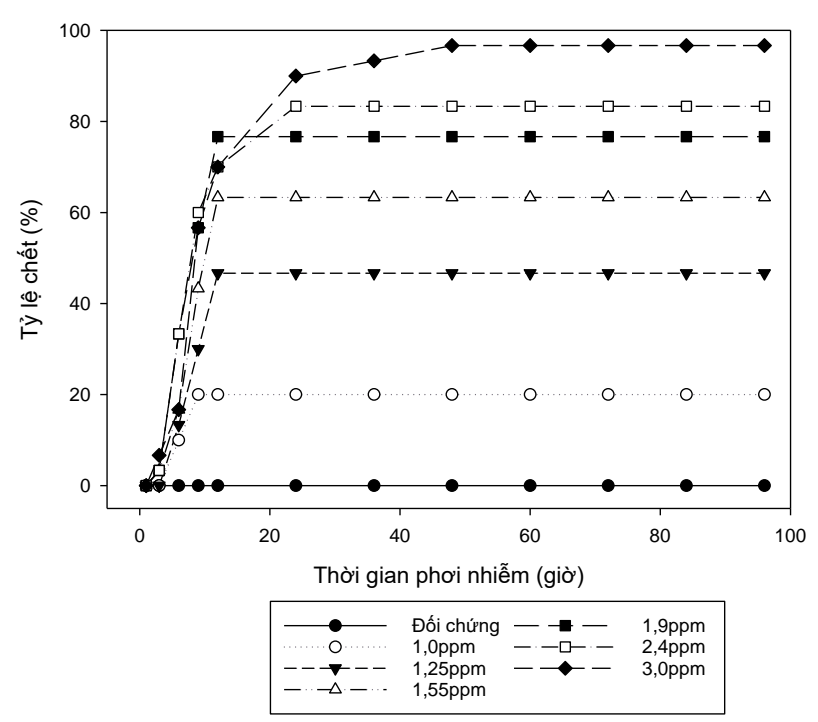

Hình 1: Tỷ lệ cá chết ở các nồng độ Marshal 200SC trong thời gian phơi nhiễm

\subsubsection{Uớc tính giá trị $L C_{50}$ theo thờ gian}

Từ kết quả tỷ lệ chết, ước tính $\mathrm{LC}_{50}$ bằng phương pháp Probit cho thấy nồng độ gây chết $50 \%$ cá mè vinh giảm dần và không đổi sau 48 giờ. Giá trị $\mathrm{LC}_{50}$ - 48 giờ của Marshall 200SC là 1,381 ppm (tương ứng $0,276 \mathrm{ppm}$ carbosulfan). Giá trị này giảm còn 1,375 ppm (tương ứng $0,275 \mathrm{ppm}$ carbosulfan) ở 48 giờ và không đổi đến 96 giờ (Bảng 2).

Giá trị $\mathrm{LC}_{50}$ là một trong những tiêu chí đánh giá nhanh độc cấp tính của hóa chất, $\mathrm{LC}_{50}$ càng nhỏ thì độc tính càng cao. Theo cách phân loại của Koesoemadinata và Djajadirecdja (1976), Carbosulfan thuộc nhóm gây độc mạnh đối với cá mè vinh cỡ giống vì có giá trị $\mathrm{LC}_{50}-96$ giờ $<1 \mathrm{mg} / \mathrm{L}$.

Bảng 2: Giá trị LC $\mathrm{LC}_{50}$ của thuốc Marshal 200SC theo thời gian

\begin{tabular}{|c|c|c|c|}
\hline \multirow{2}{*}{$\begin{array}{l}\text { Thời } \\
\text { phơi } \\
\text { (giờ) }\end{array}$} & \multirow{2}{*}{$\begin{array}{r}\text { gian } \\
\text { nhiếm }\end{array}$} & \multicolumn{2}{|c|}{$\mathrm{LC}_{50}(\mathrm{ppm})$} \\
\hline & & $\begin{array}{r}\text { Marshal } \\
\text { 200SC }\end{array}$ & Carbosulfan \\
\hline 24 & & 1,381 & $\overline{0,276}$ \\
\hline 48 & & 1,375 & 0,275 \\
\hline 72 & & 1,375 & 0,275 \\
\hline 96 & & 1,375 & 0,275 \\
\hline
\end{tabular}

Giá trị $\mathrm{LC}_{50}-96$ giờ của carbosulfan đối với một số loài cá như cá trôi (Labeo rhohita Hamilton) cỡ giống (6-8g/con) là 1,2 ppm (Nagaraju \& Venkata, 2014), cá nước ngọt Gara mullya $(6-7 \mathrm{~g} / \mathrm{con})$ là 6,98 ppm (Bansode \& Batil, 2016), cá hồi (Oncorhynchus mykiss) $(2 \pm 0,5 \mathrm{~g})$ là $0,231 \mathrm{ppm}$ (Boran et al., 2007). Qua đó cho thấy cá mè vinh cỡ giống khá nhạy cảm với carbosulfan so với một số loài cá nước ngọt khác.

Giá trị LC50-96 giờ của kinalax 25EC (chứa $25 \%$ quinalphos $)$ đối với mè vinh $(7,7 \pm 0,63 \mathrm{~g} / \mathrm{con})$ là 0,071ppm (Akter et al., 2019), của carbosulfan đối với cá mè vinh ở nghiên cứu này là $0,275 \mathrm{ppm}$. Như vậy, độc cấp tính của carbamte carbosulfan đối cá mè vinh thấp hơn lân hữu cơ quinalphos và profenofos. Các loại thuốc này đều có công dụng như nhau (BNNPTNT, 2020), được lưu hành và sử dụng ở ĐBSCL. Do đó, nếu nhất thiết phải sử dụng thuốc thì chọn thuốc ít độc sử dụng sẽ ít gây hại cho môi trường hơn.

\section{2. Ảnh hưởng của Marshal 200SC đến hoạt tính ChE cá mè vinh}

\subsubsection{Các yếu tố môi trường}

Kết quả đo đạc (Bảng 3) cho thấy nhiệt độ ở các nghiệm thức trong suốt thời gian thí nghiệm dao 
động khoảng $28,5 \pm 0,08$ đến $30,8 \pm 0,3^{\circ} \mathrm{C}$. Giá trị $\mathrm{pH}$ tương đối ổn định và đồng nhất giữa các nghiệm thức, dao động từ $7,3 \pm 0,1$ đến $7,3 \pm 0,37,3$. Hàm lượng DO ở các nghiệm thức có sự giao động trung bình trong khoảng từ 2,08 đến $3,1 \mathrm{mg} / \mathrm{L}$ và khác biệt không có ý nghĩa thống kê giữa các nghiệm thức trong buổi sáng. Tuy nhiên, buổi chiều DO ở nghiệm thức 10 và $20 \%$ LC50-96 giờ thấp hơn đối chứng khoảng $0,4 \mathrm{mg} / \mathrm{L}(\mathrm{p}<0,05)$.

Bảng 3: Nhiệt độ, pH và $\mathrm{DO}$ trong thời gian thí nghiệm

\begin{tabular}{lcrrrrr}
\hline \multirow{2}{*}{ Nghiệm thức } & \multicolumn{2}{c}{ Nhiệt độ $\left({ }^{\circ} \mathbf{C}\right)$} & \multicolumn{2}{c}{ pH } & \multicolumn{2}{c}{ DO $(\mathbf{m g} / \mathbf{L})$} \\
\cline { 2 - 7 } & \multicolumn{1}{c}{ Sáng } & Chiều & Sáng & Chiều & Sáng & Chiều \\
\hline ĐC & $28,5 \pm 0,08$ & $30,8 \pm 0,25$ & $7,3 \pm 0,1$ & $7,3 \pm 0,2$ & $3,1 \pm 0,15 \mathrm{a}$ & $2,44 \pm 0,22 \mathrm{a}$ \\
$1 \%$ LC $_{50}-96$ giờ & $28,7 \pm 0,08$ & $30,8 \pm 0,23$ & $7,3 \pm 0,2$ & $7,3 \pm 0,1$ & $2,8 \pm 0,06 \mathrm{a}$ & $2,15 \pm 0,16 \mathrm{ab}$ \\
$10 \%$ LC $_{50}-96$ giờ & $28,7 \pm 0,07$ & $30,8 \pm 0,25$ & $7,3 \pm 0,1$ & $7,3 \pm 0,3$ & $2,8 \pm 0,13 \mathrm{a}$ & $2,08 \pm 0,05 \mathrm{~b}$ \\
$20 \%$ LC C$_{50}-96$ giờ & $28,7 \pm 0,05$ & $30,8 \pm 0,33$ & $7,3 \pm 0,3$ & $7,3 \pm 0,1$ & $2,8 \pm 0,06 \mathrm{a}$ & $2,08 \pm 0,02 \mathrm{~b}$ \\
\hline
\end{tabular}

(Số liệu trình bày: Trung bình \pm độ lêch chuẩn). Trong cùng cột, số liệu theo sau cùng ít nhất 1 chũ cái thì khác biệt không có ý nghĩa thống kê, $p>0,05$, kiểm định Duncan

Trong điều kiện môi trường DO thấp, hầu hết sinh vật sẽ gia tăng khả năng lấy oxy cho nhu cầu cơ thể thông qua tăng trao đồi nước qua mang, tăng lượng hồng cầu, tăng ái lực hay khả năng gắn kết oxy với hồng cầu làm cho độc chất xâm nhập vào cơ thể nhiều hơn và gây độc nhanh hơn (Jensen $e t$ al., 1993). Vì vậy, dù DO trong khoảng cá mè vinh có thể sống sót nhưng cá phải tăng lấy oxy trong nước nên có thể làm hấp thu nhanh thuốc vào cơ thể và gây ảnh hưởng. Oxy hòa tan giữa các nghiệm thức có thuốc đều khác biệt không có ý nghĩa thống kê $(\mathrm{p}>0,05)$ nên thuốc tác động lên cá ở điều kiện oxy như nhau. Ở nghiệm thức đối chứng, oxy cao hơn các nghiệm thức có thuốc nhưng oxy không ảnh hưởng đến $\mathrm{ChE}$ cá trong điều kiện nước không bị nhiễm thuốc (Nguyễn Văn Công và ctv., 2006).

\subsubsection{Tỉ lệ úc chế ChE trong não cá mè vinh khi phoi nhiễm với Marshal 200SC}

Kết quả cho thấy tỷ lệ ức chế ChE cá mè vinh ở các nghiệm thức Marshall 200SC có xu hướng tăng dần theo nồng độ ở cùng một thời điểm thu mẩu. Tỷ lệ ức chế đạt cao nhất lúc 3 giờ rồi sau đó giảm dần và từ 48 giờ về sau không còn khác so với đối chứng (Hình 2).

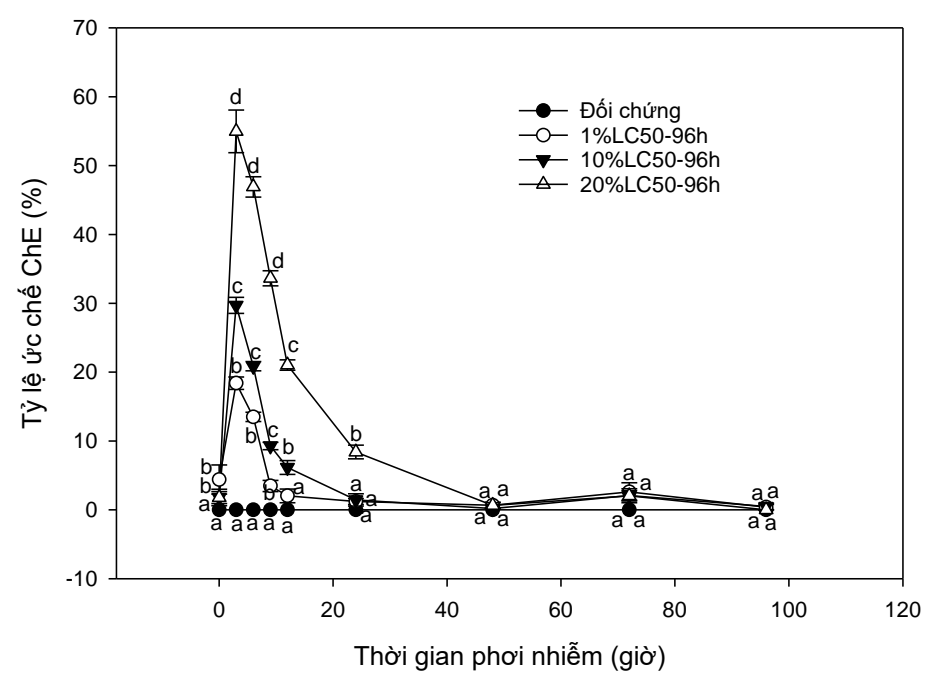

Hình 2: Tỷ lệ ức chế $\mathrm{ChE}$ cá mè vinh theo thời gian tiếp xúc với thuốc Marshal

Ghi chú: Trong cùng thời gian phơi nhiễm, giữa các đường có cùng chũ cái thì khác biệt không có ý nghĩa thống kê ( $p>0,05$, Duncan test) Số liệu trình bày: Trung bình $\pm S E$ ) 
Ở thời điểm 3 giờ sau khi tiếp xúc với thuốc, tỷ lệ ức chế $\mathrm{ChE}$ đã đạt ở nồng độ $1 \% \mathrm{LC}_{50}-96$ giờ, $10 \% \mathrm{LC}_{50}-96$ giờ và $20 \% \mathrm{LC}_{50}-96$ giờ lần lượt là $18,4 \%, 29,7 \%$ và $55,0 \%$. Theo Fulton and Key (2001), tỷ lệ ChE bị ức chế hơn $30 \%$ có thể kéo theo những ảnh hưởng bất lợi cho sinh vật và ức chế hơn $70 \%$ sẽ làm đa số sinh vật chết. Ở nồng động 0,398 ppm, carbosulfan đã làm ức chế tốc độ bắt mồi của cá rô phi 9 ngày tuổi (Pessoa et al., 2011). Tốc độ bơi lội bị ức chế và có thể làm giảm cơ hội sống sót khi cá gặp phải kẻ săn mồi hay cơ hội tìm kiếm thức ăn có thể giảm. Như vậy, nồng độ $20 \% \mathrm{LC}_{50}-96$ giờ của thuốc marshal 200SC làm ức chế ChE đến $55 \%$ nên sẽ gây ảnh hưởng có hại cho cá mè vinh. Tuy nhiên, hoạt chất này chỉ ảnh hưởng nghiêm trọng $(\mathrm{p}<0,05)$ đến tỷ lệ ức chế $\mathrm{ChE}$ cá mè vinh trong khoảng thời gian ngắn (ở các thời điểm $3,6,9$ và 12 giờ), chỉ sau 48 giờ tiếp xúc thì tỷ lệ ức chế hoạt tính ChE cá mè vinh khác biệt không có ý nghĩa giữa các nồng độ $(\mathrm{p}>0,05)$.

\section{3. Ảnh hưởng Marshal 200SC ở nồng độ dưới ngưỡng gây chết đến tăng trưởng cá mè vinh}

\subsubsection{Môi truờng trong thời gian thi nghiệm}

Nhiệt độ trong thời gian thí nghiệm tương đối đồng nhất giữa các nghiệm thức, dao động từ $27,8^{\circ} \mathrm{C}$ (buổi sáng) đến $28,3^{\circ} \mathrm{C}$ (buổi chiều) (Bảng 4).

Bảng 4. Một số yếu tố môi trường trong bể thí nghiệm

\begin{tabular}{|c|c|c|c|c|c|}
\hline \multirow{2}{*}{\multicolumn{2}{|c|}{ Thông số môi trường }} & \multicolumn{4}{|c|}{ Nghiệm thức thí nghiệm } \\
\hline & & Đối chứng & 1\%LC50-96 giờ & $10 \%$ LC50-96 giờ & 20\%LC50-96 giò \\
\hline \multirow{2}{*}{ Nhiệt độ $\left({ }^{\circ} \mathrm{C}\right)$} & Sáng & $27,8 \pm 0,2$ & $27,8 \pm 0,3$ & $27,8 \pm 0,2$ & $27,8 \pm 0,3$ \\
\hline & Chiều & $28,3 \pm 0,2$ & $28,3 \pm 0,3$ & $28,3 \pm 0,2$ & $28,3 \pm 0,3$ \\
\hline \multirow{2}{*}{$\begin{array}{l}\text { Oxy hòa tan } \\
(\mathrm{mg} / \mathrm{L})\end{array}$} & Sáng & $6,6 \pm 0,13$ & $6,6 \pm 0,16$ & $6,6 \pm 0,16$ & $6,5 \pm 0,15$ \\
\hline & Chiều & $5,8 \pm 0,13$ & $5,8 \pm 0,16$ & $5,9 \pm 0,13$ & $5,7 \pm 0,14$ \\
\hline \multirow{2}{*}{$\mathrm{pH}$} & Sáng & $7,5 \pm 0,02$ & $7,5 \pm 0,02$ & $7,5 \pm 0,02$ & $7,5 \pm 0,01$ \\
\hline & Chiều & $7,5 \pm 0,01$ & $7,5 \pm 0,01$ & $7,5 \pm 0,01$ & $7,5 \pm 0,01$ \\
\hline \multirow{2}{*}{ TAN (mg/L) } & Sáng & $0,48 \pm 0,129$ & $0,5 \pm 0,14$ & $0,5 \pm 0,14$ & $0,5 \pm 0,13$ \\
\hline & Chiều & $0,71 \pm 0,188$ & $0,6 \pm 0,16$ & $0,6 \pm 0,16$ & $0,6 \pm 0,12$ \\
\hline \multirow{4}{*}{$\begin{array}{l}\text { N_NH3+ } \\
(\mathrm{mg} / \mathrm{L}) \\
\mathrm{N}_{\mathrm{N}} \mathrm{NO}_{2}^{-} \\
(\mathrm{mg} / \mathrm{L})\end{array}$} & Sáng & $0,01 \pm 0,003$ & $0,01 \pm 0,003$ & $0,01 \pm 0,003$ & $0,01 \pm 0,003$ \\
\hline & Chiều & $0,02 \pm 0,004$ & $0,01 \pm 0,003$ & $0,01 \pm 0,003$ & $0,01 \pm 0,003$ \\
\hline & Sáng & $0,26 \pm 0,082$ & $0,25 \pm 0,077$ & $0,21 \pm 0,086$ & $0,21 \pm 0,075$ \\
\hline & Chiều & $0,28 \pm 0,078$ & $0,26 \pm 0,083$ & $0,21 \pm 0,082$ & $0,26, \pm 0,079$ \\
\hline
\end{tabular}

(Số liệu trình bày: Trung bình \pm độ lêch chuẩn. Các thông số môi truờng đều khác biệt không có ý nghia thống kê ở mức ýnghĩa 5\%, kiểm định Duncan)

Oxy hòa $\tan (\mathrm{DO})$ buổi sáng $(6,5-6,6 \mathrm{mg} / \mathrm{L})$ cao hơn buổi chiều $(5,7-5,9 \mathrm{mg} / \mathrm{L})$ và khá đồng nhất giữa các nghiệm thức. Giá trị pH trong các bể nuôi

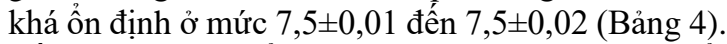
Nồng độ TAN buổi sáng ở mức $0,5 \mathrm{mg} / \mathrm{L}$ và buối chiều $0,6 \mathrm{mg} / \mathrm{L}$. Nồng độ $\mathrm{NH}_{3}$ (tính toán từ TAN dựa vào nhiệt độ và $\mathrm{pH}$ nước) thay đổi từ $0,01 \pm 0,003$ $\mathrm{mg} / \mathrm{L}$ (buổi sáng) đến $0,02 \pm 0,004 \mathrm{mg} / \mathrm{L}$ (buổi chiều). Hàm lượng $\mathrm{NO}_{2}^{-}$buổi sáng dao động từ $0,21 \pm 0,075 \mathrm{mg} / \mathrm{L}$ đến $0,26 \pm 0,082 \mathrm{mg} / \mathrm{L}$ và buổi chiều dao động từ $0,21 \pm 0,082 \mathrm{mg} / \mathrm{L}$ đến $0,26 \pm 0,08$ mg/L nhưng khác biệt không có ý nghĩa thống kê giữa các nghiệm thức.

Bảng 5: Thông số liên quan tăng trưởng cá giai đoạn 1- 60 ngày ở các nghiệm thức khác nhau

\begin{tabular}{lrrrr}
\hline Thông số tăng & \multicolumn{4}{c}{ Nghiệm thức thí nghiệm } \\
\cline { 2 - 5 } trưởng & Đối chứng & $\mathbf{1 \% L C 5 0 - 9 6 ~ g i o ̛ ̀ ~}$ & $\mathbf{1 0 \% L C 5 0 - 9 6}$ giờ & 20\%LC50-96 giờ \\
\hline FI (mg/g/ngày) & $25,8 \pm 3,281 \mathrm{~b}$ & $28,6 \pm 0,22 \mathrm{ab}$ & $29,6 \pm 0,84 \mathrm{ab}$ & $30,1 \pm 2,27 \mathrm{a}$ \\
SGR (\%/ngày) & $1,7 \pm 0,05 \mathrm{a}$ & $1,5 \pm 0,12 \mathrm{ab}$ & $1,5 \pm 0,10 \mathrm{ab}$ & $1,3 \pm 0,15 \mathrm{~b}$ \\
FCR & $2,7 \pm 0,316 \mathrm{~b}$ & $2,8 \pm 0,04 \mathrm{~b}$ & $3,1 \pm 0,14 \mathrm{ab}$ & $3,5 \pm 0,47 \mathrm{a}$ \\
Tỷ lệ sống & $100 \pm 0 \mathrm{a}$ & $94,4 \pm 3,8 \mathrm{~b}$ & $92,2 \pm 1,9 \mathrm{bc}$ & $90,2 \pm 1,2 \mathrm{c}$ \\
\hline
\end{tabular}

(Ghi chú: Số liệu trình bài trung bình \pm độ lệch chuẩn. Trong cùng một hàng, các số liệu có theo sau it nhất cùng 1 chũ cái thì khác biệt không có ýnghĩa thống kê ( $p>0,05$, Duncan test))

Kết quả nghiên cứu cho thấy trung bình lượng thức ăn tiêu thụ (mg/g/ngày) của cá mè vinh trong
60 ngày thí nghiệm ở nghiệm thức đối chứng là $25,8 \mathrm{mg} / \mathrm{g} /$ ngày. Giá trị này ở nghiệm thức thuốc $1 \%$, 
$10 \%$ và $20 \%$ lần lượt là $28,6 \mathrm{mg} / \mathrm{g} / \mathrm{ngày}, 29,6$ $\mathrm{mg} / \mathrm{g} /$ ngày và $30,1 \mathrm{mg} / \mathrm{g} /$ ngày (Bảng 5 ). Nhìn chung, FI có xu hướng tăng nhưng khác biệt không có ý nghĩa thống kê $(\mathrm{p}>0,05)$ giữa nghiệm thức đối chứng, nghiệm thức $1 \%$ và $10 \%$ LC50-96 giờ. Tuy nhiên, ở nghiệm thức 20\%LC50 - 96 giờ, FI tăng $(\mathrm{p}<0,05)$ và bằng $116,7 \%$ đối chứng). Giữa các nghiệm thức có thuốc, FI khác biệt không có ý nghĩa thống kê $(p>0,05)$.

Tốc độ tăng trưởng đặc biệt (Specific growth rate, SGR) của cá mè vinh trong 60 ngày có xu hướng giảm theo sự gia tăng nồng độ thuốc. Ở nghiệm thức đối chứng, SGR là 1,7\%/ngày; SGR ở nghiệm thức 1 và $10 \%$ LC50-96 giờ tương đương nhau và bằng $1,5 \% /$ ngày. Ở nghiệm thức $20 \%$ LC5096 giờ, giá trị SGR thấp nhất và bằng $1,3 \%$ /ngày và khác biệt so với đối chứng $(\mathrm{p}<0,05)$ (Bảng 5).

Hệ số chuyển hóa thức ăn (FCR) của cá mè vinh trong 60 ngày thí nghiệm có xu hướng tăng theo sự gia tăng nồng độ thuốc và ở nồng độ thuốc cao nhất FCR khác biệt có ý nghĩa thống kê so với đối chứng $(\mathrm{p}<0,05)$ (Bảng 5$)$. Ở đối chứng, $\mathrm{FCR}$ có giá trị là 2,7 ; FCR ở nghiệm thức nghiệm thức 1,10 và $20 \%$
LC50-96 giờ lần lượt bằng $103,7 \%, 114,8 \%$ và $129,6 \%$ đối chứng.

Qua 60 ngày thí nghiệm, cá chết không xuất hiện ở nghiệm thức đối chứng. Tuy nhiên, các nghiệm thức có thuốc đều xuất hiện cá chết. Tỷ lệ sống ở nghiệm thức 1,10 và $20 \%$ LC50-96 giờ lần lượt là $94,4 \%, 92,2 \%$ và $90,2 \%$ (Bảng 5 ).

Trọng lượng trung bình của cá ở thời điểm bố trí thí nghiệm (ngày 0 ) dao động từ $2,76-2,81 \mathrm{~g} / \mathrm{con}$ và khác biệt không có ý nghĩa thống kê giữa các nghiệm thức $(p>0,05)$. Khi kết thúc 60 ngày thí nghiệm, trọng lượng trung bình tăng từ 2,2 đến 2,7 lần so với ban đầu. Khuynh hướng trọng lượng trung bình của cá giảm theo sự tăng nồng độ thuốc Marshal 200SC. Ở nghiệm thức đối chứng, khối lượng trung bình là $7,5 \mathrm{~g} / \mathrm{con}$. Trọng lượng này ở nghiệm thức 1\% LC50-96 giờ là $6,9 \mathrm{~g} / \mathrm{con}$ nhưng khác biệt không có ý nghĩa thống kê so với đối chứng $(\mathrm{p}>0,05)$. Ở nồng độ $10 \%$ và $20 \% \mathrm{LC} 50-96$ giờ, trọng lượng trung bình cá giảm so với đối chứng $(\mathrm{p}<0,05)$ và đạt lần lượt là $6,6 \mathrm{~g} / \mathrm{con}$ và $6,1 \mathrm{~g} / \mathrm{con}$ (Hình 3).

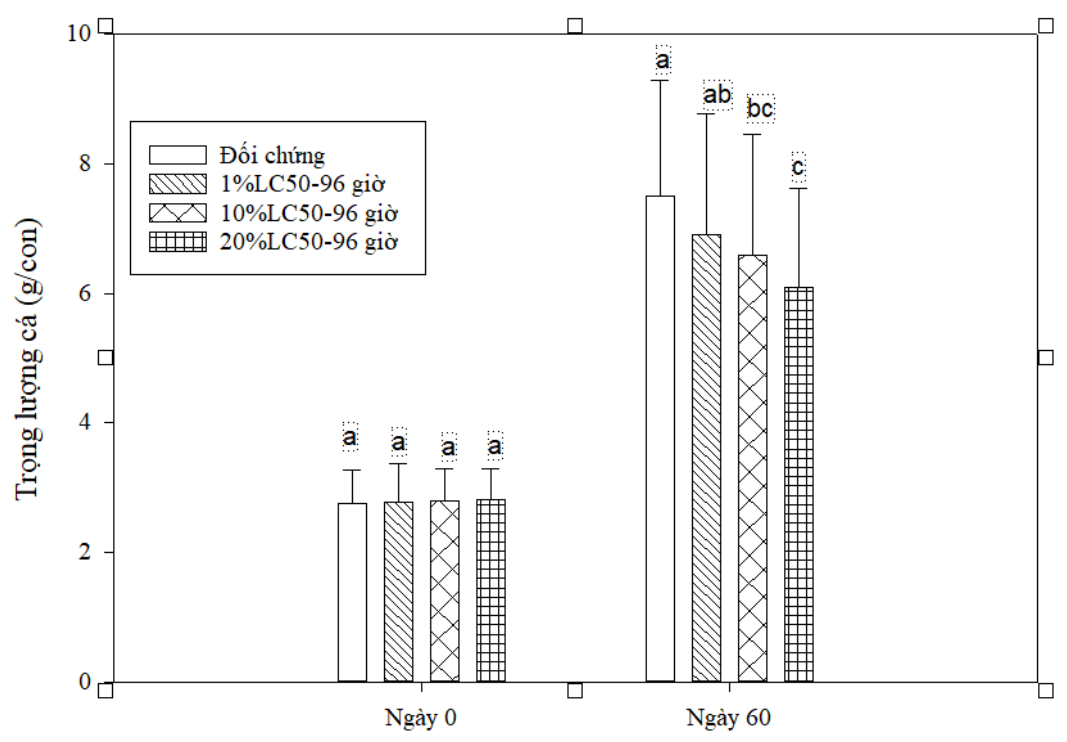

Hình 3: Trọng lượng cá thời điểm bố trí và kết thúc 60 ngày thí nghiệm

Số liệu trình bày trung bình \pm độ lệch chuẩn. Trong cùng thời điểm (ngày), các cột theo sau cùng ít nhất một chũ cái thì khác biệt không có ý nghĩa thống kê ( $p>0,05$, Duncan test)

Các yếu tố môi trường (nhiệt độ, $\mathrm{pH}, \mathrm{DO}, \mathrm{NH}_{3}$, $\left.\mathrm{NH}_{4}{ }^{+}, \mathrm{NO}_{2}{ }^{-}\right)$trong thí nghiệm tăng trưởng khác biệt không có ý nghĩa thống kê giữa các nghiệm thức. Ngoài ra, không xuất hiện cá chết (tỷ lệ sống 100\%) ở nghiệm thức đối chứng cho thây các yếu tố môi trường phù hợp cho cá sinh sống và phát triển.
Lượng thức ăn tiêu thụ $(\mathrm{FI})$ và $\mathrm{FCR}$ có $\mathrm{xu}$ hướng tăng nhưng tốc độ tăng trưởng giảm và chỉ có nghiệm thức 20\%LC50-86 giờ khác biệt so với đối chứng. Khi phơi nhiễm với chất độc ở nồng độ dưới ngưỡng gây chết sinh vật thường cần nhiều năng lượng để giải độc nên ăn nhiều hơn điều kiện bình thường. Nghiên cứu của McGeer et al. (2000) cho 
thấy cá hồi (Oncorhynchus mykiss) tăng sử dụng thức ăn trong 35 ngày phơi nhiễm với nồng độ dưới ngưỡng gây chết của đồng $\left(\mathrm{Cu}^{2+}\right)$ nhưng tăng trọng không ảnh hưởng và giải thích cá cần sử dụng năng lượng cho giải độc. Hoạt chất thuốc bảo vệ thực vật carbaryl gây ức chế tăng trưởng cá da trơn Mystus vittatus (Arunachalam et al., 1980) và cá Macropodus cupanus (Arunachalam \& Palanichamy, 1982). Qua phân tích trao đổi chất và hiệu quả chuyển hóa thức ăn, các tác giả đã đi đến kết luận tăng trưởng bị ức chế là do cá tăng sử dụng năng lượng cho hô hâp bao gồm tăng hoạt động nắp mang và lấy khí trời. Cong et al (2009) cho thấy khi cho cá lóc phơi nhiễm với nồng độ dưới ngưỡng gây chết của diazinon trong 60 ngày (15 ngày thay mới dung dịch thí nghiệm/lần) thì SGR có xu hướng giảm theo sự gia tăng nồng độ diazinon; giá trị SGR sau 60 ngày nuôi ở nồng độ 0,35 ppm đã bị ức chế $33 \%$ so với đối chứng.

Trong nghiên cứu này, FI, FCR cá mè vinh tăng, SGR giảm nhưng chỉ ở nồng độ cao nhất (20\%LC50-96 giờ) khác biệt so với đối chứng. Có thể cá mè vinh cũng cần năng lượng cho chống chịu với stress do tiếp xúc với carbosulfan nên tăng sử dụng năng lượng lấy từ thức ăn cho giải độc hơn tích lũy cho tăng trọng hay lớn lên.

Carbosulfan ít bền trong môi trường, thời gian bán hủy ở điều kiện $20^{\circ} \mathrm{C}, \mathrm{pH} 7-8,5$ dao động từ $4,2-5,4$ ngày và 7 ngày ở $\mathrm{pH} 9$ (EFSA, 2006). Giá trị $\mathrm{pH}$ trong nghiên cứu này dao động trong khoảng $7,0-7,5$ (Bảng $1,3,4$ ). Do đó, trong $\mathrm{pH}$ này, carbosulfan có thể đã bị phân hủy nhanh chóng, dẫn tới nồng độ giảm nhanh. Nghiên cứu ở Nhật cho thấy dù carbosulfan được sử dụng nhưng không phát hiện thuốc tồn dư trong môi trường nước (Iwafune et al., 2010). Nghiên cứu ở Trung Quốc cũng cho kết quả tương tự như ở Nhật (Zhang et al., 2016). Sản phẩm thủy phân của carbosulfan là carbofuran và dibutylamine (EFSA, 2006). Do đó, dù carbosulfan đã giảm nhưng sản phẩm thuỷ phân của carbosulfan vẫn còn tồn tại và có thể gây ảnh hưởng cho cá.

Dù gây ảnh hưởng không lâu nhưng hoạt tính ChE ở cá mè vinh bị ức chế ngay ở nồng độ $1 \%$ LC50-96 giờ $(\mathrm{p}<0,05)$; trong khi các thông số tăng trưởng chỉ bị ảnh hưởng $(\mathrm{p}<0,05)$ ở nồng độ 20\%LC50-96 giờ. Qua đó cho thấy hoạt tính ChE nhạy cảm hơn thông số tăng trưởng của cá.

\section{KẾT LUẬN VÀ KIẾN NGH!}

\subsection{Kết luận}

Marshal 200SC chứa carbosulfan 200g/L có độ độc cấp tính cao đối với cá mè vinh cỡ giống, giá trị LC50-96 giờ của thuốc đối với loài cá này là 1,375 ppm (tương đương $0,275 \mathrm{mg} / \mathrm{L}$ Carbosulfan). Hoạt tính của $\mathrm{ChE}$ trong não cá mè vinh nhạy cảm với Marshal 200SC hơn chỉ số tăng trưởng. Ở nồng độ 1\%LC50-96 giờ thuốc đã làm ức chế 18,4\% hoạt tính ChE; trong khi ở nồng độ 20\%LC50-96 giờ, thuốc làm $\mathrm{FCR}$ và $\mathrm{FI}$ tăng lần lượt bằng $129,6 \%$ và $116,7 \%$ đối chứng nhưng SGR giảm còn $74,5 \%$ đối chứng.

\subsection{Kiến nghị}

Nghiên cứu ảnh hưởng của Marshal 200SC lên cá mè vinh ở điều kiện đồng ruộng là cần thiết để hiểu rõ hơn ảnh hưởng của sử dụng thuốc này đến cá trong thực tế ruộng lúa.

\section{LỜI CẢM TẠ}

Nghiên cứu này được tài trợ bởi Dự án Nâng cấp Trường Đại học Cần Thơ VN14-P6 bằng nguồn vốn vay ODA từ chính phủ Nhật Bản.

\section{TÀI LIỆU THAM KHẢO}

Akter R., Parvin A., Jahan H., \& Hossain Z. (2019). Impact of Kinalax 25 EC on Vital Organ Histomorphology, Blood Cell Structure and Brain Acetylcholinesterase Activity in Silver Barb (Barbonymus gonionotus). Aquaculture Studies, 19(2), 103-111.

Akter R., Parvin A., Jahan H., \& Hossain Z. (2019). Impact of Kinalax $25 \mathrm{EC}$ on Vital Organ Histomorphology, Blood Cell Structure and Brain Acetylcholinesterase Activity in Silver Barb (Barbonymus gonionotus). Aquaculture Studies, 19(2), 103-111.

American Publish Health Association (APHA). (1998). Standard Methods for the Examination of Water and Wastewater. $20^{\text {th }}$ edition, Washngtion, D.C., pp. 8-1 to 8-25.

Arunachalam S. \& Palanichamy, S. (1982). Sublethal effects of carbaryl on surfacing behavior and food utilization in the air-breathing fish, Macropodus cupanus. Physiol. Behav. 29(1), 2327. DOI: 10.1016/0031-9384(82)90360-2

Arunachalam S., Jeyalakshmi K. \& Aboobucker S. (1980). Toxic and sublethal effects of carbaryl on freshwater catfish, Mystus vittaus (Bloch). Arch. Environ. Contam. Toxicol., 9(3), 307-316. DOI: 10.1007/BF01057410 
Bansode S.B., \& Patil R.D. (2016). Relative toxicity of bifenthrin and carbosulfan Fresh water fish gara mullya (sykes). Biolife, 4(2), 482-484.

Berg H., \& Tam N. T. (2012). Use of pesticides and attitude to pest management strategies among rice and rice-fish farmers in the Mekong Delta, Vietnam. International Journal of Pest Management, 58(2), 153-164.

Boran M., Altinok U., Capkin E., Karacam H., \& Bicer V. (2007). Acute Toxicity of Carbaryl, Methiocarb, and Carbosulfan to the Rainbow Trout (Oncorhynchus mykiss) and Guppy (Poecilia reticulata). Turk. J. Vet. Anim. Sci, 31(1), 39-45.

Bộ Nông nghiệp và Phát triển nông thôn. (2020). Thông tu (10/2020/TT-BNNPTNT) ban hành Danh muc thuốc bảo vệ thưc vật được phép sủ dụng, cấm sủ dụng tại Việt Nam.

Cong N. V., Phuong N. T., \& Bayley M. (2008). Brain cholinesterase response in the snakehead fish (Channa striata) after field exposure to diazinon. Ecotoxicology and Environmental Safety, 71, 314- 318.

Cong N. V., Phuong N. T., \& Bayley M. (2006). Sensitivity of brain cholinesterase activity to diazinon (BASUDIN 50EC) and fenobucarb (BASSA 50EC) insecticides in the air-breathing fish Channa striata (Bloch, 1793). Environmental Toxicology and Chemistry, 25(5), 1418-1425.

Cong N.V., Danh D.T., \& Nam T.S. (2021). Effects of Chlorpyrifos Ethyl on Cholinesterase and Growth of Silver Barb (Barbonymus gonionotus). Water 13, 2885. https://doi.org/10.3390/w13202885

Cong N.V., Phuong N.T., \& Bayley M. (2009). Effects of repeated exposure of diazinon on cholinesterase activity and growth in snakehead (Channa striata). Ecotoxicol. Environ. Saf., 72, 699-703.

Ellman G. L., Courtney D., Anderdres V. J., \& Featherstone R. M. (1961). A new and rapid colorimetric determination of acetylcholinesterase activity, Biochemistry and Pharmacology, 7, 88 - 95.

European Food Safety Authrity (2009). Scientific Report: Conclusion on the peer review of carbosulfan. EFSA Journal, 7(10), 1-112.

Finney, D.J. (1971). Probit Analysis, 3rd ed. Cambridge University Press, Euston, London, UK.

Fulton M. H., \& Key P.B. (2001). Annual review: Acetylcholinesterase inhibition in stuarine fish and invertebrates as an indicator of organophosphorus insecticide exposure and effects. Environmental Toxicology and Chemmistry 20 (1): 37-45
Iwafune T., Inao K., Horio T., Iwasaki N., Yokoyama A., \& Nagai T. (2010). Behavior of paddy pesticides and major metabolites in the Sakura River, Ibaraki, Japan. J. Pestic. Sci., 35(2), 114-123. DOI: 10.1584/jpestics.G09-49

Jensen F. B., Nikinmaa M., \& Weber R. E. (1993). Environmental perturbations of oxygen transport in teleost fishes: causes, consequences and compensations. In: J. Cliff Rankin and Frank B. Jensen (ed), Fish Physiology, Chapman and Hall.

Koesoemadinata S., \& Djajadiredja R. (1976). Some aspects on the regulation of Agriculture use of Pesticides in Indonesia, with preference to their effects on inland fisheries, IFRI Contribution (No. 3), pp14.

Lê Huy Bá. (2000). Độc học môi truoòng. Nhà xuất bản ĐHQG TPHCM.

McGeer J.C., Szebedinszky C., McDonald D.G., \& Wood C.M. (2000). Effects of chronic sublethal exposure to waterborne $\mathrm{Cu}, \mathrm{Cd}$ or $\mathrm{Zn}$ in rainbow trout. 1: Ionoregulatory disturbance and metabolic costs. Aquat. Toxicol., 50, 231-243.

Nagaraju B., \& Venkata R.V. (2014). Determination of median lethal concentrations (LC50) of freshwater fish Labeo rohita (Mamilton) for carbosulfan and its behavioral impacts. Journal of stress physiology and biochemistry, 10(3), 218-231.

Nguyễn Trần Oánh, Phạm Văn Biên \& Bùi Trọng Thủy. (2007). Giáo trình sủ dụng thuốc BVTV. Nhà xuất bản Nông nghiệp Hà Nội.

Nguyễn Văn Công, Trần Sỹ Nam, Phạm Ngọc Thanh Hùng \& Nguyễn Thanh Phương. (2006). Ảnh hưởng nhiệt độ và oxy hòa tan lên độc tính Basudin 50EC ở cá lóc (Channa striata BLOCH 1793). Tạp chí Khoa học Truò̀ng Đại hoc Cần Tho, 1-12.

Nguyễn Văn Toàn \& Nguyễn Văn Công. (2018). Hiện trạng sử dụng thuốc bảo vệ thực vật ở một số vùng canh tác lúa đồng bằng sông Cửu Long. Tạp chí Tài nguyên và Môi trường, 5(283), 26-30.

Pessoa P.C., Luchmann K. H., Ribeiro A. B., Veras M. M., Correa J. R. M., Nogueira A. J., Bainy A. C. D., \& Carvalho P. S. M. (2011). Cholinesterase inhibition and behavioral toxicity of carbofuran on Oreochromis niloticus early life stages. Aquatic Toxicology, 105(3-4), 312-20.

Stenersen, J. (2004). Chemical Pesticides. Mode of Action and Toxicity. CRC Press, Boca Raton, London.

Tam N. T., Berg H., \& Cong N.V. (2018). Evaluation of the joint toxicity of chlorpyrifos ethyl and fenobucarb on climbing perch (Anabas testudineus) from rice fields in the Mekong Delta, Vietnam. Environ Sci Pollut Res. Ecotoxicology In Tropical Regions., 25(17), 17207-17215. 
Tomlin C., (ed.). (1994). The Pesticide Manual: Incorporating the Agrochemicals Handbook, 10th ed. British Crop Protection Publications, Surrey, UK.

Trương Thủ Khoa \& Trần Thị Thu Hương. (1993). Định danh các loài cá nước ngọt Đồng Bằng Sông Củu Long, Việt Nam, Khoa Thủy Sản, Trường Đại học Cần Thơ.

Võ Văn Hà, Nguyễn Duy Cần \& Đặng Kiều Nhân. (2004). Xác định mực nước tốt nhất cho lúa và cá trong hệ thống canh tác lúa-cá nước ngọt ở đồng bằng sông Cửu Long. Tap chí Khoa hoc Truòng Đại học Cần Tho, 1, 137-146.

Zhang C. P., He H. M., Yu J. Z., Hu X. Q., Zhu Y. H., \& Wang Q. (2016). Residues of carbosulfan and its metabolites carbofuran and 3-hydroxy carbofuran in rice field ecosystem in China. Journal of Environmental Science and Health, Part B Pesticides, Food Contaminants, and Agricultural Wastes, 51(6), 351-357. 